\title{
Synthesis of results from the Comprehensive Biodiversity Survey of Bukit Timah Nature Reserve, Singapore, with recommendations for management
}

\author{
L. Chan ${ }^{1} \&$ G.W.H. Davison ${ }^{2}$ \\ ${ }^{1}$ International Biodiversity Conservation Division, National Parks Board, \\ 1 Cluny Road, 259569 Singapore \\ Lena_Chan@nparks.gov.sg \\ ${ }^{2}$ National Biodiversity Centre, National Parks Board, \\ 1 Cluny Road, 259569 Singapore
}

\begin{abstract}
Twenty-two papers arising from the Comprehensive Biodiversity Survey of Bukit Timah Nature Reserve (BTNR), Singapore (2014-2018) have provided a thorough update and expansion of information on many groups of flora and fauna. In spite of the small size and isolation of BTNR there is still remarkable diversity, and new records and new species continue to accumulate. A large body of information on the terrestrial and aquatic physical environment is now available, providing a context for many of the biological results. Various management recommendations emerge.
\end{abstract}

Keywords: Nature Conservation Masterplan, conservation policy, fauna, flora.

\section{Introduction}

The importance of conserving Bukit Timah Nature Reserve (BTNR) has been highlighted in an Introduction to the Comprehensive Biodiversity Survey of Bukit Timah Nature Reserve (Chan \& Davison, 2019). The nature reserve is of continuing national importance. National biodiversity conservation policies make use of sound science, and the Nature Conservation Masterplan (National Parks Board, 2015) is a keystone document to biodiversity conservation matters. In turn, management strategies and operational plans are guided by the science-based policies. The National Parks Board (NParks) has built up technical capacity to drive scientific research, formulate policies and translate them into action plans in partnership with a wide range of dedicated stakeholders. This comprehensive biodiversity survey of BTNR illustrates how the entire life-cycle of biodiversity conservation is being implemented.

There is a long history of research having been carried out in BTNR. The detailed notebooks, publications and specimens of Alfred Russel Wallace provide good documentation of the natural history of Singapore in the middle of the nineteenth century, much of it derived from the vicinity of Bukit Timah. A historical review of BTNR is included in this volume (Davison \& Chew, 2019). Most recently, Chin et al. (1995) and Chan \& Corlett (1997) have presented the results of past surveys on many plant and animal groups. 
As mentioned in the introductory paper to this volume, from 2014 to 2018 the National Parks Board organised a similar survey of the BTNR alone (Chan \& Davison, 2019) with several structured and organised features that made it significantly different from the other surveys.

\section{Outputs}

The 1992 review of BTNR resulted in publication of a supplement to the Gardens' Bulletin Singapore (Chin et al., 1995) containing 168 pages and 15 papers. Concurrently, Turner et al. (1994) had compiled a paper on interesting plant records. In addition, several unpublished reports, now lodged with the National Biodiversity Centre, were submitted by Gupta (1992), Kang (1992), Murphy (1993), Turner et al. (1992) and Yang et al. (1992).

The 1993-1997 survey covered both BTNR (163 ha) and CCNR (3043 ha, including about 2600 ha land area plus the surface areas of five reservoirs). The subsequent issue of the Gardens' Bulletin Singapore (Chan \& Corlett, 1997) contained 280 pages and 11 papers by Balke et al. (1997), Chew et al. (1997), Corlett (1997), Khew \& Neo (1997), Lim (1997), Murphy (1997), Ng (1997), Ng \& Lim (1997), Seow-Choen (1997), Teo \& Rajathurai (1997) and Yang et al. (1997).

The 2014-2018 survey, covering only BTNR and its immediate surroundings, has resulted in the present Supplement to the Gardens' Bulletin Singapore.

Table 1 compares the topics covered by the three main publications.

\section{Participation}

In Table 2 we have compiled rough estimates of time and manpower utilised for each survey topic during the 2014-2018 survey. Time spent in fieldwork has been emphasised, but some teams were also able to estimate laboratory processing time, sorting or imaging separately. The numbers are not intended to be exact, but to give an indication of the extent to which the National Parks Board is obliged to specialists and volunteers for their time and expertise.

\section{Objectives}

The objectives of this synthesis are:

1. To highlight the key findings of all the taxonomic groups surveyed, the studies carried out on the physical features of BTNR and the genomics of the insects encountered during the surveys; and

2. To recommend measures for conserving and sustaining the biodiversity of BTNR, including measures now in use and those that have potential for the future. 
Table 1. Comparison of topics covered by three main publications on Bukit Timah Nature Reserve, Singapore.

\begin{tabular}{llcc}
\hline Topic & 1995 & 1997 & 2019 \\
\hline ECOLOGY & & \\
\\
Vegetation & + & + \\
& Physical geography & & + \\
& Freshwater ecology & & \\
\hline
\end{tabular}

\section{FLORA}

Angiosperms

Pteridophytes

Rubiaceae

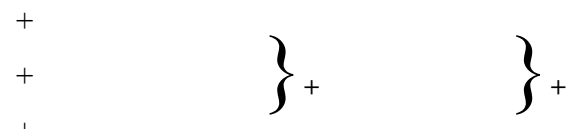

Bryophytes

Algae

$+$

Mycorrhizae

Macrofungi

$+$

\section{FAUNA}

Macaques

Mammals

Reptiles, amphibians

Birds

Fishes

Decapod crustaceans

Semi-aquatic bugs

Water beetles

Saproxylic beetles

Dragonflies

Stick insects

Butterflies

Moths

Orthoptera

Bees

Springtail-catching flies

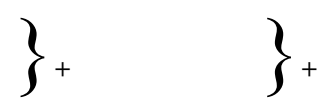

\}+

Spiders

Other arthropods barcoding 
Table 1. Continuation.

\begin{tabular}{lll}
$\boldsymbol{G E N E R} \boldsymbol{A}$ & & \\
Introduction & + & + \\
History & + & + \\
Review & + & + \\
\hline
\end{tabular}

\section{Compilation of the survey results and analyses}

The area of BTNR is only 163 hectares, with a high point at 163.6 metres elevation. The area of Singapore is currently 71,990 hectares (Department of Statistics Singapore, 2018), making Singapore 440 times larger than BTNR. In other words, BTNR is only $0.23 \%$ the area of Singapore.

\section{Plants}

The 1208 native species of flora found in BTNR account for 55\% of the estimated 2215 native species in Singapore (B.C. Ho et al., 2019). They include 167 species (80 tree species, 61 climbers, 12 shrubs, 13 herbs plus one epiphyte) previously not listed from BTNR. The species accumulation curve did not reach a plateau, indicating that with extra efforts, more species could be found. Of the 454 species previously recorded from BTNR that were not found in this study, 108 are already recorded as likely to be nationally extinct in Singapore (Davison et al., 2008; Chong et al., 2009). It should also be noted that the current surveys were carried out in sample plots and this was not an inventory, hence the undetected species could be due to a data collection artefact. From the overlap of 354 species found in both primary and old secondary forest it could be inferred that there is recruitment of primary forest species into the regenerating forest. Forest rehabilitation, enhancement and restoration should be carried out, to arrest degradation of the different forest types. Since Dipterocarpaceae are entirely absent from the maturing young secondary forest, active enhancement of dipterocarp species in the younger forests may be required. Ecological studies of phenology, dispersal agents, pollinators, etc. should be pursued. Weeding of invasive species of Dicranopteris and Dioscorea should be intensified, even though some are native, as they suppress regeneration. The buffer parks already established will help to prevent drying and edge effects.

In addition to the main survey results, several recent publications have compiled new plant records for BTNR. They include Artabotrys scortechinii King recorded by Chen et al. (2018), new to Singapore; 13 species reported by Ho et al. (2018) of which three were new to Singapore; 16 tree species found in surveys of BTNR by Khoo et al. (2018), all new to Singapore; and two of the species (Dendrokingstonia nervosa (Hook.f. \& Thomson) Rauschert and Phyllanthus reticulatus Poir.) published by Lim et al. (2018) as new to Singapore. 
Table 2. An estimate of manpower and time devoted to each topic in the comprehensive biodiversity study of Bukit Timah Nature Reserve, Singapore.

\begin{tabular}{|c|c|c|}
\hline Topic & $\begin{array}{l}\text { No. of } \\
\text { researchers and } \\
\text { assistants }\end{array}$ & No. of fieldwork hours or days \\
\hline Flora & 40 & $1635 \mathrm{hrs} / 327$ days \\
\hline Macrofungi & 12 & $27 \mathrm{hrs} / 9$ days \\
\hline $\begin{array}{l}\text { Mammals, reptiles \& } \\
\text { amphibians }\end{array}$ & 66 & > $5331 \mathrm{hrs} \mathrm{/} \mathrm{>} 222$ days \\
\hline Birds & 4 & $12 \mathrm{hrs} \times 12$ sessions $=144 \mathrm{hrs}$ \\
\hline Spiders & 20 & $\begin{array}{l}\text { Beating quadrats } 60 \text { hours. } \\
\text { Litter sampling } 40 \text { hours } \\
\text { Many hours sorting and identifying }\end{array}$ \\
\hline Bees & 10 & $460 \mathrm{hrs}$ \\
\hline Butterflies & 8 & Fieldwork 96 hrs; desk work 40 hrs \\
\hline $\begin{array}{l}\text { Dragonflies } \\
\text { and damselflies }\end{array}$ & 3 & $120 \mathrm{hrs}$ \\
\hline Moths & 2 & $\begin{array}{l}22 \text { fieldwork sessions } \\
\text { Many hours sorting and identifying }\end{array}$ \\
\hline Orthoptera & 1 & $51 \mathrm{hrs}$ \\
\hline Saproxylic beetles & 1 & $120 \mathrm{hrs} / 30$ days \\
\hline $\begin{array}{l}\text { Other arthropods and } \\
\text { DNA barcoding }\end{array}$ & 20 & $\begin{array}{l}\text { Fieldwork: } 256 \text { hours ( } 62 \text { days over } 14 \text { months) } \\
\text { Pre-sorting to order: }>400 \text { hours } \\
\text { DNA and imaging work: ca. } 2-5 \text { manpower years }\end{array}$ \\
\hline $\begin{array}{l}\text { Freshwater } \\
\text { stream systems }\end{array}$ & 5 & $160 \mathrm{hrs}$ \\
\hline Freshwater fish & 8 & $284 \mathrm{hrs}$ \\
\hline Freshwater crustaceans & 8 & $20 \mathrm{hrs}$ \\
\hline
\end{tabular}

Bryophytes of BTNR were reviewed by Wee \& Mohamed (1995) who listed 15 liverworts and 48 mosses. They were not included in the 1993-1997 or the 2014-2018 surveys, but Ho (2002) listed 71 mosses from BTNR while Piipo et al. (2004) listed 23 species of liverworts and hornworts with definite records from BTNR. Twenty of 
the 23 liverworts are supported by recent collections (from 1998 onwards), while Ho (2013) has added a new record, Marchantia emarginata Reinw. et al., at the outskirts of BTNR. Blepharostoma trichophyllum (L.) Dumort., listed for BTNR by Wee \& Mohamed (1995), is not supported by vouchers but is widespread in the tropics and certainly possible for Singapore. Piipo et al. (2004) noted the historical loss of $40 \%$ of the liverwort flora of Singapore and noted particularly heavy losses among epiphyllic Lejeuneaceae and ground-living Bazzania species. They considered drying within forest fragments due to exposure and ground disturbance to be two important factors.

It was observed in the survey that there are only a few individuals of many of the extant plant species. To ensure their long-term survival, species recovery actions must be carried out.

\section{Big trees}

An analysis of the Comprehensive Biodiversity Survey of BTNR would be incomplete without incorporating the findings of the permanent plot measuring 2 ha that was established within the primary forest zone of BTNR in 1993 under the Smithsonian Institution's worldwide Centre for Tropical Forest Science (CTFS) network (LaFrankie et al., 2005). CTFS has recently been renamed the Forest Global Earth Observatory (ForestGEO). The BTNR plot is a long-term collaboration between the National Institute of Education, the Nanyang Technological University of Singapore, ForestGEO and the National Parks Board. It is one of the longest continuously running biological monitoring programmes in Singapore. Within the plot, every tree of $1 \mathrm{~cm}$ or greater diameter at breast height (dbh) has been tagged, mapped, measured and identified to species level. The trees are re-surveyed at fairly regular intervals to monitor growth and mortality. At least 341 tree species are represented (LaFrankie et al., 2005), and these include at least 16 species newly recorded for Singapore (Khoo et al., 2018). An additional 2 ha plot of secondary forest vegetation was added in 2004. In addition, big trees over $30 \mathrm{~cm}$ dbh were mapped throughout the 163 ha area of BTNR during the period 2005-2008.

Early results suggested no short-term loss in species or abundance and gave no indication that the primary forest was giving way to secondary forest through degradation and intrusion (Ercelawn et al., 1998). No particular group of trees (e.g., monoecious versus dioicous species, different size classes, differing dispersal mechanisms) seemed at that time to be suffering a dearth of regeneration, except possibly the Myristicaceae, of which the fruits are typically consumed whole and dispersed by large vertebrates (Ercelawn et al., 1998).

The most abundant tree species comprises more than $10 \%$ of all stems of $1 \mathrm{~cm}$ dbh or greater, but up to at least 2012 there continued to be no evident loss of species diversity across the periodic censuses and size classes. However, the forest is very dynamic, characterised by high mortality and recruitment rates in comparison with less fragmented forests in the region. By 1998 there had been a 20\% reduction in the number of stems, and decreased biomass, but by 2008 the number of stems had recovered to 1993 levels. Over the period to 2012, annual mortality among 12,688 stems was 3.3\% but this was balanced by recruitment (Ngo et al., 2016). There 
was no discernible advantage or disadvantage to plants with different life history characteristics, such as emergent versus sub-canopy growth type, or animal versus non-animal dispersal. Few signs of forest degradation could be detected, although decadal scale consequences of climate change could be anticipated (Ngo et al., 2016). Shifts in species abundance require further attention.

Chua et al. (2013) enumerated trees across the whole of BTNR in three vegetation zones approximating to the primary forest, old secondary forest and maturing secondary forest zones mentioned by Chan \& Davison (2019). Within 85 ha of primary forest there were 338 species and 4324 individual trees of $30 \mathrm{~cm} \mathrm{dbh}$ or greater; within 85 ha of approximately 56-year-old secondary forest there were 294 species and 5073 individuals; and within 8 ha of maturing secondary forest there were 43 species and 911 individuals (Chua et al., 2013). The primary forest did not contain any non-native tree species (LaFrankie et al., 2005). The 2 ha plot of old secondary forest had $30 \%$ of stem density, $58 \%$ of basal area, $26 \%$ of species richness, and $59 \%$ of Shannon diversity as compared with the 2 ha primary forest plot (Chua et al., 2013). The old secondary forest is now characterised by disturbance-adapted species such as Dillenia suffruticosa (Griff. Ex Hook. f. \& Thomson) Martelli, Adinandra dumosa Jack and Campnosperma auriculata Hook. f. (LaFrankie et al., 2005; Goldsmith et al., 2011). Several shade tolerant species such as Streblus elongatus (Miq.) Corner and Calophyllum spp. thrive in the secondary forest (Chua et al., 2013). Various mechanisms accounting for the slowness of recovery of the secondary forest include strong limitations on dispersal, and the long-term survival of pioneer species (Chua et al., 2013). The younger, maturing secondary forest, termed 'degraded forest' by Goldsmith et al. (2011), although it could be described as regenerating pioneer vegetation over degraded soils, has a lower, more open canopy and includes understorey patches of ferns Dicranopteris spp. (Gleicheniaceae) and the pitcher plant Nepenthes gracilis Korth. that Corlett (1991) and others consider to be indicators of higher light and poorer soil characteristics. The old secondary and maturing secondary zones show greater depth of leaf litter, lower seedling density, and lower seedling height (i.e., poorer growth) than does the primary forest. Burslem et al. (1995) conducted ex situ growth experiments on seedlings from the forest understorey and Turner et al (1997) described floristic differences of primary and old secondary forest based on conditions in the nearby CCNR. Additional data and analyses of the growth performance of native tree species on degraded lands were given by Shono et al. (2006, 2007). Work has been conducted on the flowering phenology of Shorea species; flowering overlap, hybrid vigour and possibly environmental factors apparently act in favour of hybrids (Kenzo et al., 2019).

\section{Macrofungi}

Tham \& Watling (2017) included 230 taxa in their list of the fungi of Bukit Timah Nature Reserve, and Bukit Timah is the type locality for 98 or $42 \%$ of these taxa. Yet $70 \%$ of macrofungi in the region may yet be undiscovered or undescribed (Lee et al., 2008) and curation of existing collections is still at an early stage in forming a basis for further studies (Lee, 2019). 
Vertebrates (mammals, reptiles and amphibians)

Terrestrial vertebrates were surveyed by Teo \& Thomas (2019). They found a total of 81 indigenous species including 18 amphibians, 40 reptiles and 23 mammals. The updated inventory comprises 115 species including 21 amphibians, 60 reptiles and 34 mammals ever historically recorded within BTNR. $61 \%$ of species $(84 \%$ of amphibians, $55 \%$ of reptiles, $57 \%$ of mammals) were documented by both Teo \& Rajathurai (1997) and the current survey, while 21\% (5\% of amphibians, $27 \%$ of reptiles, $20 \%$ of mammals) were reported only by Teo \& Rajathurai (1997), and $18 \%$ (11\% of amphibians, $18 \%$ of reptiles, $23 \%$ of mammals) were recorded only in the current survey.

Mammals form one of the few groups in which reassembly of an animal community can be followed. Since 1997 the fauna has been augmented by wild boar Sus scrofa, Malayan porcupine Hystrix brachyura, Sunda slow loris Nycticebus coucang, and Sumatran palm civet Paradoxurus musangus. All would have been past members of the historical fauna, lost through development pressures, and are thought to have increased in Singapore in the recent past. The wild boar has become common in many localities by breeding rapidly and moving freely through urban and disturbed landscapes. Populations of slow loris and palm civets in BTNR have possibly been augmented by escaped pets or deliberate releases. It will be interesting to see if there are further gains (e.g., sambar deer Rusa unicolor; lesser mousedeer Tragulus kanchil) through colonisation from the Central Catchment Nature Reserve.

Officers from the National Biodiversity Centre (NBC) carried out nocturnal surveys for the species recovery programme during the period from 2017 to 2019 . Their sighting records concur with the ranking order of sightings by the team conducting the Comprehensive Biodiversity Survey of BTNR. They used thermal imaging equipment along with the more traditional spotlighting with headlamps and flashlight. A combination of several survey methods including the above mentioned methods accompanied by transect surveys, camera trapping, small mammal trapping, mist netting, passive and active ultrasonic bioacoustics recorders would ensure a thorough 24-hour coverage. Rare and shy animals could also be detected by camera trapping.

\section{Birds}

The total number of birds ever recorded for BTNR is now 146 species (Lim, 2019). The 1993-1997 survey recorded 114 species from BTNR and the 2014-2018 survey recorded 68 species from BTNR. The Bird Group of the Nature Society (Singapore) has been conducting its own Annual Bird Census (ABC) in the meantime and the cumulative total number of species recorded during the census at BTNR from 1997 to 2015 inclusive was 87 species. Some of the differences in the species sighted during the three surveys could be attributable to the different experimental designs applied, including the length of the entire survey period, whether the surveys were diurnal or/and nocturnal, the lengths of the line transect, and survey methodologies such as whether mist-netting was used, etc. 
Few of the species are entirely and strictly forest dependent, though many make use of both primary and disturbed forest environments. Nevertheless, there are additional very interesting records obtained by birdwatchers recently. They include Zappey's Flycatcher Cyanoptila cumatilis (newly distinguished from Blue-and-White Flycatcher C. cyanomelana), Sakhalin Leaf-warbler Phylloscopus borealoides (newly recorded for Singapore and for Southeast Asia, and now recorded there over several years), Narcissus Flycatcher Ficedula narcissina at Dairy Farm (second record for Singapore) and Verditer Flycatcher Eumyias thalassinus from Dairy Farm (first record for Singapore) (Singapore Bird Group, 2018; Yap et al., 2014). Some new records are attributable to human intervention, e.g. Red Junglefowl, Gallus gallus and White-crowned Laughingthrush, Garrulax leucocephalus (Lim, 2019). Although the number of species encountered during this current survey appears to be lower than during the other two surveys, i.e., 1996-1997 and the 1997-2015 ABC, it is important to note that the number of key species has remained constant.

Total forest area available, forest quality, and connectivity with other forests such as CCNR will be critical factors in determining the future survival of forest-dependent species.

\section{Spiders}

Spiders were surveyed comprehensively for the first time during the 2014-2018 survey (Koh \& Court, 2019). So far 223 species in 42 families have been named, with a likely total of more than 317 species amongst those analysed so far, including representatives of five families not previously listed from BTNR. Some ecological niches (e.g., litter close to streams and the forest canopy) were not sampled, and the many records of singletons suggest that many more species will be found. There is a large backlog of collected but unidentified or unnamed material still to be processed. About 33 species previously recorded from BTNR were not found (Koh \& Court, 2019); some may have been missed because of incomplete sampling. Despite not finding some previously recorded spider species the survey has firstly revealed the amazing species richness of spiders in BTNR, and secondly, BTNR still remains the refuge of a plethora of species that are new to science and endemic to Singapore. These findings are supported by the discovery of at least six potential or putative new species (Koh \& Court, 2019), concurring with the recent research literature that includes a list of recently described spiders from BTNR and the adjoining Dairy Farm Nature Park (Huber et al., 2016; Tong et al., 2016; Koh \& Court, 2019) comprising Ovia macritchie, Ischnothyreus poculum, Paculla bukittimahensis, Paculla globosa, Tissahamia bukittimah, Singaporemma lenachanae and Sulamania brevis, as well as 25 new Singapore records.

The spider researchers expect to reach a higher number of species once the sorting and identification is completed. Even allowing for previous misidentification and possible double-counting, the net total is still a staggering one for such a small patch of nature reserve. 
Bees

The compilation of historical and recent records yielded a list of 55 bee species recorded from BTNR and 61 species from the adjacent Dairy Farm Nature Park (Asher et al., 2019), giving a total of 75 species in all. Of these, 64 species are included in post-2000 records. Four eusocial stingless bees and one species of solitary bee are likely to be extinct in Singapore. However, solitary bee species new to Singapore continue to be discovered at BTNR like the Megachile spp.

The bee community of the forest canopy was not surveyed in 2014-2018. The continuous flowering of both native forest-edge shrubs and non-native weeds may be crucial for maintaining bee populations between infrequent mass flowering of the forest canopy (Ascher et al., 2019). The vegetation of Dairy Farm and Rifle Range Nature Parks, containing more freely flowering shrubs and weeds, therefore has a role to play in conservation of bees able to exploit the primary forest trees of BTNR when they are in flower.

\section{Butterflies}

During the 2014-2018 survey, 63 species of butterflies were found within BTNR and 85 species in the adjacent nature parks (Khew \& Tan, 2019). Of the 63 species within BTNR, 27 or $43 \%$ were not found in the nature parks, particularly shade-loving species of Nymphalidae. The combined total was 112 species, one third of Singapore's total butterfly fauna.

As also found for bees (Ascher et al., 2019), the diversity of butterflies in the buffering nature parks can be attributed to the availability of forest edge vegetation, open sunny conditions, and freely flowering shrubs and weeds as nectar sources. Just as nectar sources in secondary vegetation may provide a 'bridge' for bees in between occasional mass flowering years in the forest (Ascher et al., 2019), and as streams provide larval habitat for dragonflies whose adults disperse more widely (Cai et al., 2019), so for butterflies the plant species diversity within the forest may provide larval food sources and ecological niches for pupation that help to support the wider butterfly populations.

\section{Dragonflies and damselflies}

The current survey found 43 species of dragonflies and damselflies (36 during quantitative surveys and another seven during ad hoc observations), new locality records bringing the total ever recorded to 55 species for BTNR including the adjacent nature parks (Cai et al., 2019). There were striking differences between locations, with between one and 16 species per site, meaning that sustainability of the total community depends on maintaining the full range of site conditions.

Studies have concentrated on flying adults, and the stream requirements for larvae of different species are poorly understood. As for the Singapore freshwater crab Johora singaporensis, stream water acidification might have a conservation impact. Other hydro-geomorphological changes to the streams in BTNR may also affect the odonate fauna. Mitigation measures need to be based on multi-disciplinary study of stream hydrology and ecology in BTNR. Long-term monitoring is needed to build on 
current knowledge and capture long term trends, using standardised survey techniques and sampling protocols. Other management options include stream rehabilitation and enhancement, the reintroduction of native species to their original habitats, and the development of public outreach and education.

\section{Moths}

No comprehensive survey of moths had been performed in BTNR, nor indeed in Singapore, until the 2014-2018 survey (Karam \& Chong, 2019). The survey yielded some 399 species, of which 200 have so far been named. Significant gaps in the moth fauna recorded so far include the scarcity of hawkmoths and atlas moths, although further observations are likely to fill such gaps amongst species that occur periodically or that have large population fluctuations.

No obvious correlation has yet been found between moon rise, the moon phases and rainfall versus the number of moths that were attracted to light traps. Nor are the effects of light pollution understood. The lack of historical information is a hindrance. Therefore, the current survey results are more significant as a baseline for future monitoring than as an indicator of past change, as is also the case for orthopterans (Tan, 2019).

\section{Orthoptera}

In total, 83 species of Orthoptera have been recorded from BTNR (Tan, 2019), including 30 from the suborder Caelifera (grasshoppers and relatives) and 53 from the suborder Ensifera (crickets, katydids, and relatives). Of the 83 species, 42 have been collected during the past decade, but survey results are not directly comparable because earlier collectors emphasised day-time collecting and recent surveys emphasised night-time collecting. Inferences on extinctions, population, rarity or abundance, and distribution should be made with caution.

The current checklist can be used as a baseline for future comparisons. More information is needed on the ecology and natural history of various species, if orthopterans are to be used as indicators or model organisms for the management of BTNR.

\section{Saproxylic beetles}

A.R. Wallace collected 133 species of Cerembycidae and at least 22 species of Buprestidae, thought to be largely or exclusively from the vicinity of Bukit Timah, in 1854. The 2014-2018 survey recorded 38 cerambycids and 15 buprestids (Cheong, 2019). The larger and more spectacular species found by Wallace were not detected, while the current totals are maintained only by finding more of the small and less conspicuous forms. Possibly ten of the recently discovered species are new records for Singapore, but there are many taxonomic uncertainties among these beetles. Possibly ten of the recently discovered species are new records for Singapore, but there are many taxonomic uncertainties among these beetles.

The results suggest underlying challenges to the survival of beetles (and other invertebrates) that are dependent on dead and decaying wood. Among the factors are 
the small total area of forest, short distances to forest edges and hence susceptibility of the entire forest to edge effects, lengthening of intervals between available tree falls (because a smaller forest area has fewer trees and therefore fewer tree deaths) (Cheong, 2019).

Steps to conserve saproxylic beetles would probably assist the conservation of macro-fungi and vice versa: maintaining soil moisture and retaining fallen litter of all sizes including fallen tree trunks, boughs and smaller branches to rot naturally in position.

\section{Springtail-catching flies}

This is the first time that findings on Dolichopodidae, or indeed any dipteran flies, have been included in coordinated surveys of BTNR. It is also noteworthy that two species, Neurigona temasek and Neurigona timahensis, out of the three found in BTNR are new species discovered during the survey period (Grootaert \& Foo, 2019). Next Generation Sequencing 313bp barcodes of new species cited in taxonomic papers in this paper indicates the importance of the inclusion of genomic data. It has been postulated that the presence of these conspicuous dolichopodid flies is a good bioindicator of human influence on ecosystems and climate change. More research on their presence, species diversity, and abundance could help understand their ecological roles and their potential as bioindicators.

\section{Stick insects}

A previous survey listed 41 species of stick and leaf insects for Singapore, of which eight had not been recorded for more than 30 years, leaving 33 probably extant species (Seow-Choen, 1997). The total was increased to 44 species by Seow-Choen (2017). Sixteen species have been recorded historically from BTNR. Of these, 11 were found during the 2014-2018 survey (nine were common), while the other five are known to be nationally rare so might still have been detected with increased survey effort (Seow-Choen et al., 2019).

The rare species are ones for which the food plants are unknown, pointing to the need for better information to guide insect conservation through attention to plant diversity in and around BTNR.

\section{Other arthropod species and barcoding}

During the last comprehensive biodiversity of BTNR and CCNR, genomics was still in its infancy. The progress made in this field has opened up new horizons in the identification and documentation of arthropod diversity. Using genomics helps in the grouping of specimens into species since there is such a high number of arthropod species, with differing life stages and poorly known morphological characters. For this exercise, only selected groups of arthropods, i.e., Diptera, Hemiptera, Hymenoptera, and Araneae were sequenced (J.K.I. Ho et al., 2019).

Hemiptera species are found in all the forest types, i.e., maturing secondary forests, primary forests, and old secondary forests. While each forest zone shares about 100 species with each other, many species were found only in specific 
ecosystems. Since the species accumulation curve had not reached a plateau during sampling, it is highly likely that more Hemiptera species will be found. The species diversity in BTNR is found to be much higher than in mangroves, freshwater swamp forests or disturbed forest sites in Singapore.

Currently, it is commonly accepted that Coleoptera has more species on earth than any other order of insects, but more recent studies indicate that the species diversity of Hymenoptera and Diptera might exceed that of Coleoptera.

A rough estimate of the number of insect species in Singapore could be more than 50,000 - far greater than the known number of vertebrates. Due to the diversity of insect species, so will be the range and scope of their ecological functions. The total biomass contributed by insects could far outweigh that of all the other faunal groups. Extrapolating from the small sample size of the Hemiptera study, it is anticipated that similar trends could be expected among Hymenoptera and Diptera that are thought to be even more species rich. With the reduction of the cost of genome sequencing, it is now a reality to completely sequence, carry out DNA barcoding and identify the entire biodiversity of Singapore. The inclusion of genome sequences of species in scientific papers is now a common practice, making the information much more available to a wider audience.

\section{Terrestrial environment}

Research on the physical environment of BTNR appropriately complements the biodiversity component of the survey. The value of long-term monitoring is clearly demonstrated by studies of the terrestrial environment that span over 13 years from 2004 to 2017 (Chatterjea, 2019). It enables researchers and NParks' officers to carry out comparative analyses of the physical health of BTNR and correlate them with visitor numbers. It is noteworthy that a number of timely intervention management decisions like the closure of trails and BTNR have resulted in the recovery of its physical condition. Reduction of human impact on the unpaved trails allows for the restoration of permeability of the soil which would then increase the retention of the top organic soil layer, nutrients and facilitate the infiltration of water. The research also revealed that repair work instituted on an ad hoc basis only served as a stop-gap measure while a complete closure provided sufficient time to implement a coordinated thorough repair and restoration works to the slopes, trails and forested areas (Chatterjea, 2019). The involvement of volunteers and the residents in creating public awareness of the BTNR closure was a good way of building up community stewardship. Learning from this recent experience, the current strategy of minimising the impacts of anthropogenic activities through direct and active intervention periodically would appear to be the best option to protect BTNR.

\section{Hydrogeomorphic characteristics of streams}

The ten streams arising within BTNR have been truncated downstream by land clearance and development beginning in the nineteenth century, and they have been affected since then by the varied history of the different forest zones. Past and present activities are responsible for alterations to the rate and type of erosion processes, 
water temperature, sediment load, and many other features. Fascinating historical information is available from the Dairy Farm area on malaria control measures implemented in the 1930s (Stewart, 1931), with effects still seen today. In spite of these changes, it is remarkable how resilient the streams, and the aquatic fauna within them, have proven to be. Preliminary results show that the majority of the steam channel reaches studied are functioning well, except that moderate to intense erosion was observed at the middle reaches of Lasia and Dairy Farm streams, and at the lower reaches of Fern Valley and Wallace streams, where instability, undercutting of banks and bank failure have caused significant widening and down-cutting of the stream channels. In general, the streams in Bukit Timah have little sediment, with low and small-sized sediment bars visible only at the lower reaches of Fern Valley, Lasia and Wallace streams, which should not significantly affect the stream function if culverts and lined drains downstream are well maintained. However, several artificial pools near the outlets of Taban, Seraya and Catchment streams and the middle of Jungle Fall stream continuously receive upstream sediments loads and accumulation of sediment with distinct siltation have obviously degraded the instream habitats (Cai, 2019).

BTNR is one of few sites in Singapore that retain small lowland streams with natural beds running beneath closed canopy forest. Many of Singapore's endemic species inhabit these freshwater streams. It is also the most likely ecosystem in which to find endemic species in the future as the streams are isolated from any other freshwater aquatic sites by the Straits of Singapore and Straits of Johor. However, any newly discovered endemics in future could come from poorly known groups such as caddisflies and stoneflies.

\section{Physicochemical characteristics of streams}

For the first time, a comprehensive collection of research data has been compiled on the physicochemical characteristics of all ten streams arising within BTNR. It is one of the very few studies in the region that focus on small lowland forest headwater streams. The data will form the baseline for future long-term monitoring exercises, highly relevant to the conservation of native freshwater fishes, dragonflies, damselflies, crustaceans and other animal groups with life stages dependent on the streams (Nguyen \& Cai, 2019).

Although the source of these ten streams is confined to a very small area, multiple complex factors contribute to determining the characteristics of the streams. This dynamic flux between abiotic and biotic factors has created unique features in each of the ten streams.

Some urgent action needs to be taken to elucidate the reasons for the acidification of Jungle Fall stream in particular, to ensure the survival of endemic freshwater species. The relatively high levels of $\mathrm{Cd}, \mathrm{Sb}$, and $\mathrm{Se}$ in stream water warrant further scientific studies. A comprehensive long-term monitoring plan for the physicochemical properties of the soil, rainfall and groundwater is crucial for a holistic understanding of the unique stream system in BTNR, for its sustainability and the conservation of aquatic biodiversity in the nature reserve. 


\section{Freshwater fishes}

Twelve freshwater fishes were listed for BTNR and its immediate surroundings by Lim (1995), by which time ten were still extant, one possibly lost from BTNR and one nationally extinct. $\mathrm{Ng} \&$ Lim (1997) listed 17 species from BTNR. Of the 27 freshwater fish species documented by the 2014-2018 survey, 16 are native to Singapore and 11 are introduced ( $\mathrm{Li}$ et al., 2019). Two native species known from other parts of the Central Catchment Nature Reserve were recorded for the first time in BTNR.

BTNR remains a key conservation area for freshwater fauna. However, there are still threats from changing hydrological regimes, invasion of introduced species at the outskirts and potential developments in the periphery. Introduced fish species have increased in both diversity and abundance in the past twenty years, possibly aggravated by concretisation at the lower reaches of streams, altering water conditions, and increased accessibility to the streams by the public. The causes of the increasing acidification of streams in BTNR (including litter decomposition) are still only partly understood but can lead to a long-term reduction in diversity of the freshwater fauna (Feldman \& Connor, 1992; Courtney \& Clements, 1998).

Where possible, mitigation measures should be implemented to prevent further invasion of the introduced species. Recommendations include monitoring, regular removal of the introduced species, and enforcement against illegal release of unwanted pets in the nature reserve. Enhancing streamside vegetation, especially near the edges of BTNR, can help to minimise bank erosion and lower the water temperature, while retaining woody debris in the streams contributes to preserving the natural habitat of the native species, providing a more suitable environment for the natives over introduced species which generally tolerate disturbed habitats.

\section{Freshwater crustacea}

Out of the eight native freshwater decapod crustaceans known from BTNR, four freshwater crabs, three freshwater prawns and one crayfish species were recorded during the 2014-2018 survey (Khoo et al., 2019). An introduced species, the prawn Macrobrachium lanchesteri was newly recorded at one site on the periphery of the reserve. The native freshwater crab Geosesarma nemesis was not recorded in this survey, possibly because it is a semi-terrestrial species for which the water-based sampling methods were unsuitable.

The results suggest that each species (three of which are endemic to Singapore) have specific freshwater habitat requirements and their detailed distribution within BTNR therefore depends on the specific conditions within each stream. Stream acidification is one of the conservation concerns, as are total water flow, the amount of residual water remaining during very dry weather, and bank erosion. Concerns over freshwater crustaceans (Khoo et al., 2019) are very similar to those applying to dragonflies (Cai et al., 2019) and fishes (Li et al., 2019). 


\section{Lessons learned}

Some expertise is irreplaceable. Specialists on particular taxa have built up their knowledge over decades, and their contributions cannot be matched when the experts are no longer available. Investment in research opportunities (not necessarily financial support, but providing opportunities for young specialists to develop their skills) will be crucial to the quality of future surveys. Reliance on volunteers is an excellent way: firstly, to tap on the best expertise in each specific field; secondly, to involve as many stakeholders as it is administratively efficient; thirdly, to strengthen the citizen science community so as to forge community stewardship; and fourthly, to build capacity in new volunteers and younger people.

Imposing common methodologies, common transects and common timing upon varied research topics does not always work. It is more practical to request coverage of the main zones and allow individual research groups to decide on how to cover them best. What is more important is to ensure that the experimental designs are scientifically sound and rigorous

New technologies are becoming available, from camera traps and thermal imaging binoculars to barcoding and environmental DNA. The effectiveness of the more traditional survey methods like transect surveys, small mammal trapping, mist netting, spotlighting with headlamps and flashlights, etc. would be greatly enhanced by new technologies that are becoming available like thermal imaging binoculars, camera trapping, passive and active ultrasonic bioacoustics recorders, barcoding, environmental DNA, drone photography, etc. An assemblage of these diverse methods would ensure a thorough 24-hour coverage over a long uninterrupted survey period, hence increasing the probability of detecting rare and shy animals and transient visitors.

\section{Recommendations}

The recommendations arising from the comprehensive biodiversity survey can be broadly categorised into the four thrusts of NParks' Nature Conservation Masterplan (NParks, 2015):

1. Conservation of key habitats,

2. Habitat enhancement, restoration, and species recovery,

3. Applied research in conservation biology and planning, and

4. Community stewardship and outreach in nature. 
Conserving a diverse range of ecosystems

All the papers in this volume have demonstrated that high diversity in the different taxonomic groups is based on specific habitat requirements, and hence, the need to conserve the diverse range of ecosystems found in BTNR. Different stages of ecological succession and varied ecosystems, i.e., primary rain forest, old secondary forest, young maturing secondary forest, streams, ponds, open areas, gaps, etc., are important for the survival of the diverse species found in the reserve. Moreover, the intricate and complex inter-dependency of species that have evolved over eons in time is far beyond our limited knowledge. Hence, any anthropogenic disruption might tilt unexpected tipping points, particularly in times of climate change uncertainty.

The importance of conserving all the streams in BTNR cannot be overemphasised as they differ from each other and harbour their own unique composition of freshwater fauna and flora (Cai, 2019; Cai et al., 2019; Khoo et al., 2019; Li et al, 2019; Nguyen \& Cai, 2019).

\section{Nature parks acting as buffer and protective zones}

Green zones like Hindhede, Dairy Farm, Rifle Range and Bukit Batok Nature Parks are extremely important to buffer the nature reserve from the effects of development outside BTNR (Fig. 1). Nature parks provide complementary ecosystems to those in BTNR as observed in the survey results on butterflies and bees (Ascher et al., 2019; Khew \& Tan, 2019). Nature parks can also take pressure off the core areas in BTNR that are more sensitive to the impact of humans visiting. Government has successfully expanded the network of nature parks around BTNR and should continue to intensify this safeguarding of nature parks in the immediate vicinity of BTNR (Chatterjea, 2019) and further afield like Bukit Gombak, Tengah, etc. Conversely, nature parks also benefit from the exchange and dispersal of genetic resources by being close to BTNR.

\section{Connectivity}

BTNR and CCNR used to be a contiguous forested entity, allowing wildlife to range freely. In 1983, the construction of the Bukit Timah Expressway (BKE) commenced. When the BKE was completed in 1986, it fragmented the central forests of Singapore into the 163 ha BTNR and 3043 ha CCNR. These two terrestrial biodiversity hotspots were finally re-connected via the Eco-Link@BKE (Fig. 2) in 2013. The Eco-Link@ BKE plays a pivotal role in connecting BTNR and CCNR ecologically. Monitoring surveys using camera trapping are already recording the use of this crossing by wildlife such as mammals, birds, and butterflies (Chung et al., 2018). With the success of the Eco-Link@BTNR functioning as an ecological corridor for varied species, it is now timely to explore other sites for modes of reconnecting BTNR and CCNR more extensively.

In addition to functioning as protective buffer zones for BTNR, nature parks also act as important ecological connections for mammals, birds, butterflies, bees, dragonflies, and for the dispersal of plants. The planting of native forest plant species along roads such as Upper Bukit Timah Road and BKE can further augment 
ecological connectivity. Ecological connectivity can be extended to reach urban parks and gardens, facilitating the movement and range of many animal taxa.

\section{Habitat enhancement and restoration}

Launched in January 2019, the Forest Restoration Action Plan (FRAP) will facilitate forest plant species to get a stronger foothold and ultimately improve habitats for animal species. Enhancing and restoring the forest through the FRAP adhere to the principle that good quality habitats are essential for providing homes for all the other species.

Stream enhancement initiatives should mirror those for the terrestrial habitat, for the survival of freshwater fish, decapods, dragonflies and other aquatic plant and animal species (Cai, 2019; Cai et al., 2019; Khoo et al., 2019; Li et al, 2019; Nguyen \& Cai, 2019).

\section{Species recovery}

The collection of seeds during mast fruiting of dipterocarps and other forest species for propagation by NParks' Native Plant Nursery is an obvious step to secure a stock and gene bank of our native flora.

The presence of a sizeable population of wild boar Sus scrofa in BTNR, that was not present during the previous survey, is of conservation concern due to their rooting and nesting behaviour that might have negative impacts on important ground flora and the seedlings of forest tree species (Teo \& Thomas, 2019).

Specific habitat enhancement and restoration actions should be taken to assist in increasing the bird diversity and abundance. Re-introduction programmes for species that show obvious signs of decline, in particular the stenotopic forest species that are also nationally or globally threatened (Lim, 2019), should be considered seriously. NParks has a species recovery programme for bird species in which all relevant stakeholders can work together to advance bird conservation in a coordinated and cohesive manner.

Urgent action should be taken to eliminate introduced and invasive species like the White-crested Laughingthrush Garrulax leucolophus, and stricter enforcement against poaching (Lim, 2019).

Ex situ breeding of endemic species and re-stocking them in the wild has been successful in the case of the endemic Singapore freshwater crab, Johora singaporensis. This experience can be applicable to other endemic freshwater species that require exigent attention.

As there are so few headwater streams left in Singapore, several proactive initiatives like 1) keeping out invasive alien species by providing more resources for monitoring and physical removal of invasive alien species and illegal release of unwanted pets; 2) enhancing riparian vegetation along the banks of streams that would help minimise bank erosion and lower the water temperature; 3) retaining woody debris in streams that contributes to retaining the natural habitats of native species; 4) conducting research on why the $\mathrm{pH}$ in streams has dropped; and 5) imposing the requirement of carrying out an EIA and an EMMP for any developments inside and 


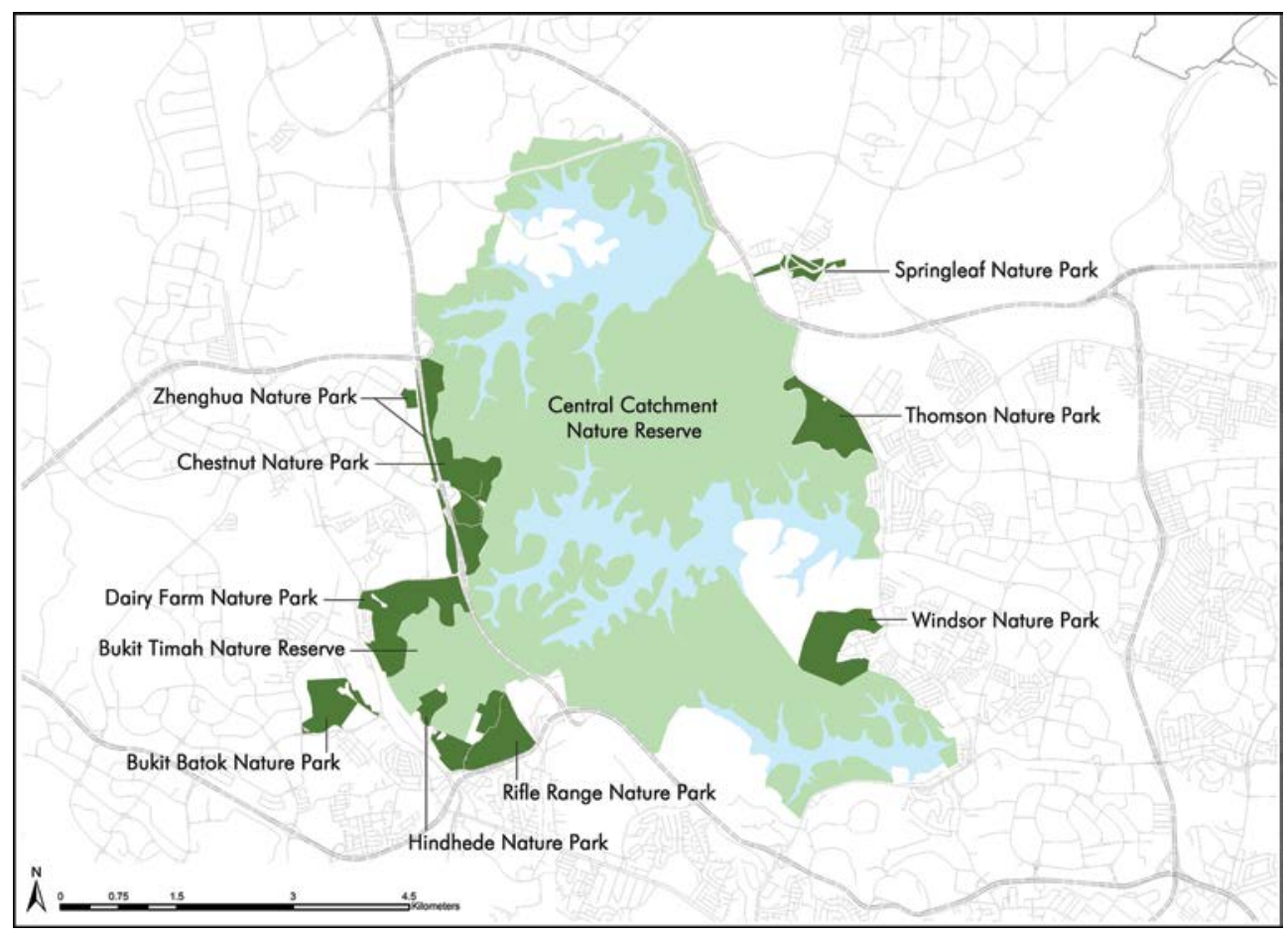

Fig. 1. Map of the Nature Parks surrounding and in the vicinity of Bukit Timah Nature Reserve, Singapore. (Source: NParks)

outside BTNR that would affect the freshwater streams has been recommended (Li et al., 2019; Khoo et al., 2019).

To conserve the native dragonfly and damselfly species, it has been recommended that native species be introduced into their original habitats (Cai et al., 2019). Stick insects may require a different approach, as some species are very fastidious about their food plants, and it would be necessary to actively plant their food plants (some not yet known) in areas where they have been observed (Seow-Choen et al., 2019).

A call has been made to initiate the conservation of trapdoor spiders Monodontium bukittimah and other spiders that have been recorded from BTNR and nowhere else in Singapore (Koh \& Court, 2019).

\section{Future surveys}

A first survey of the nature reserves was conducted in 1993-1997, and the second survey of Bukit Timah Nature Reserve was conducted in 2015-2016. This is an interval of approximately 20 years, and we consider this appropriate for the following reasons.

A substantial survey cycle takes about five years to complete: a year of planning, two years available for fieldwork (bearing in mind the need to procure 
equipment and chemicals, start-up time, installation of equipment, etc.), two years for compilation, analysis and writing, and a year for publication. Only a very large or a very small survey would greatly change the time needed. Five years of effort every 20 years seems manageable. Surveys every 20 years will pick up fairly large changes and yield publishable findings on long term trends, without going into great detail monitoring small variations that would overly burden the manpower available. Over a 20-year period, there will be some continuity of personnel including experts on particular topics, but also some changes.

There may well be particular topics that require much more regular monitoring, for example water or air quality, or weather readings. These can be organised separately as they have different manpower, timetabling and budget requirements.

Expansion and diversification of current accepted scientific methods used to sample insect diversity, including flight intercept traps, pitfall traps (J.K.I. Ho et al., 2019) will inevitably augment the chances of finding new species. For bees, deployment of malaise traps in the canopy may reveal new species (Ascher et al., 2019). It is also important to cover niches in BTNR that are not currently reached, e.g., forest canopy and below ground. Pro-active efforts must be made to broaden taxonomic groups to include soil-dwelling invertebrates like nematodes, earthworms, ciliates, etc.

\section{Research}

Several researchers have recommended research topics to be pursued. Since forest trees have a long lifespan, it is crucial to carry out studies on the recruitment of iconic primary forest families like Dipterocarpaceae to ensure that recruitment occurs, and to take proactive steps to enhance planting if recruitment is not observed (B.C. Ho et al., 2019). This should be carried out using an ecological approach, coordinating it with research on arthropod pollinators, and dispersal agents like birds and other vertebrates for animal dispersed tree families.

Now that the taxonomy of Orthoptera is quite well researched, the next challenge is to study its ecological interactions with other species. Orthoptera contribute to the diet of many vertebrates, but they could be important pollinators, useful indicators or model organisms for conservation management (Tan, 2019).

Koh \& Court (2019) have suggested verification of the hypothesis that the primary forest is a hotspot for the rarer spider species associated with more pristine forests, and not found in secondary forests within BTNR and other localities outside BTNR. This has management implications and applications, including zonation of core areas.

\section{Management practices}

In addition to conservation and research recommendations, many researchers echoed a similar recommendation to retain fallen logs, preferably in their natural position as they provide a range of microhabitats for macro-fungi (Lee, 2019), saproxylic bettles (Cheong, 2019), spiders (Koh \& Court, 2019), and presumably other invertebrates. 


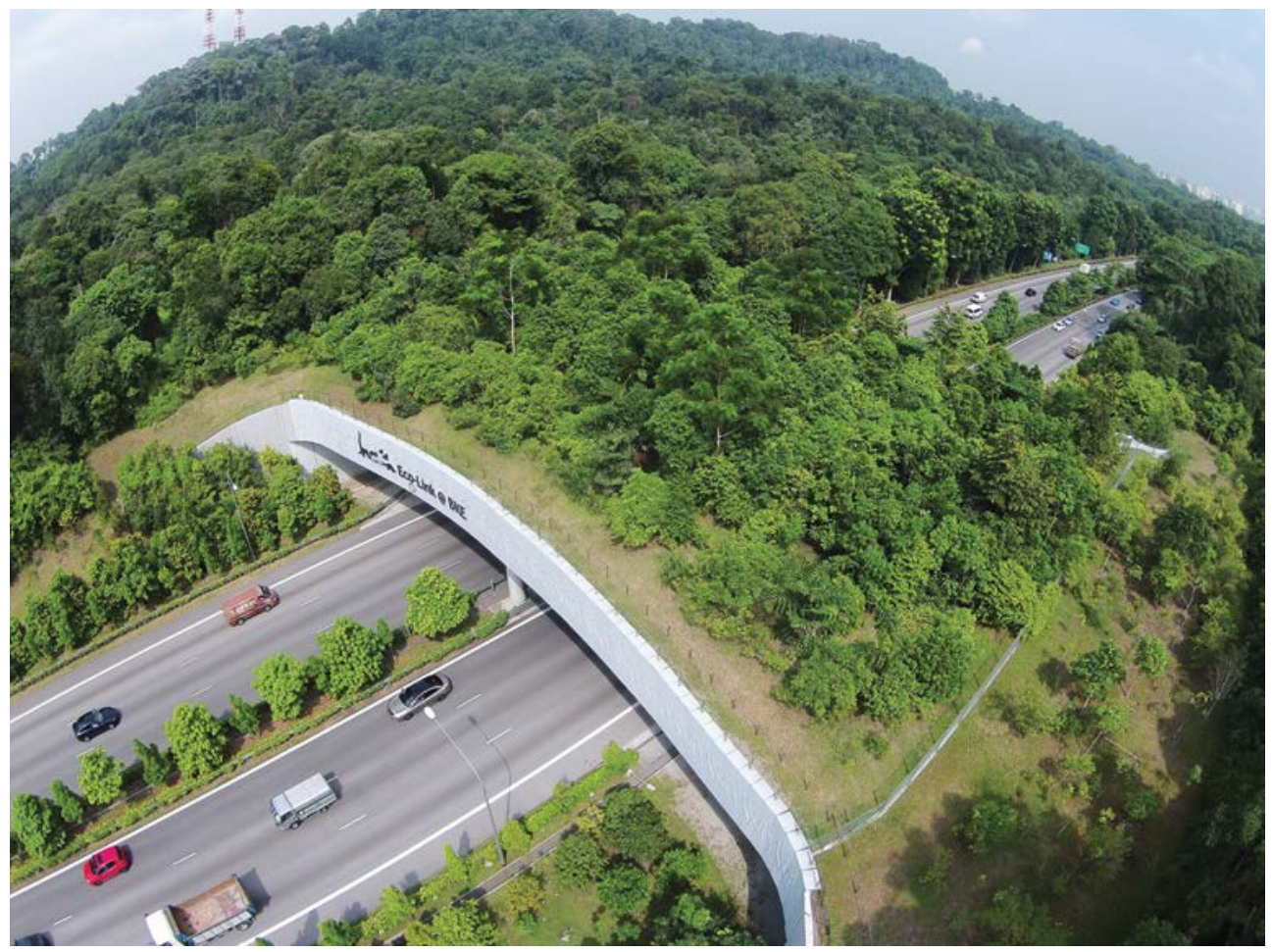

Fig. 2. An aerial photograph of the Eco-Link @ BKE (Bukit Timah Expressway. (Photo: T.W. Wong)

Continuous flowering of both native forest-edge shrubs like Melastoma malabathricum L. and non-native weeds such as Asystasia gangetica (L.) T.Anderson subsp. micrantha (Nees) Ensermu may be crucial for the maintenance of insect populations in the years between mass flowering of the forest canopy (Ascher et al., 2019; Khew \& Tan, 2019)). Planting a greater diversity of plant species with nectar to suit the specific demands of adults and caterpillars of butterflies will increase their long-term survival (Khew \& Tan, 2019), particularly in nature parks but not in BTNR as some of the plants could be non-native species.

Long-term monitoring of biodiversity and the health of the physical environment, in particular the physicochemical characteristics of streams, of BTNR is crucial (Cai, 2019; Chatterjea, 2019; Nguyen \& Cai, 2019). The results can assist in a sound science-based decision-making process. If deemed necessary, closure of BTNR could be effected periodically to restore and enhance holistically all of BTNR's biodiversity and ecosystem services.

In complex ecosystems where many factors interplay, modelling studies can better help to elucidate the hydrogeomorphic function of streams and the extent of climate change and other anthropogenic impacts on the integrity of the streams in the near future and longer term (Cai, 2019). This can guide stream management in a 
scientific manner (Cai, 2019) for adaptation, mitigation, and to build resilience against climate change effects.

Due attention must be accorded to maintaining nutrient cycling and the physical environment in BTNR. As and when necessary, trails should be closed periodically (Chatterjea, 2019) for the restoration of ecosystem services provided by the soils, and for recovery of trailside vegetation.

Nature parks should be managed as an integral part of BTNR as they provide many complementary and supporting ecosystems, forming a seamless ecological gradient.

\section{Community stewardship and public awareness outreach}

The strong support and active participation of the community and residents around BTNR is an exemplary demonstration of community stewardship. This should be showcased as a successful partnership of the public with the government.

\section{Conclusions}

Table 3 compares the number of species in BTNR, the number of species in Singapore, and the number of species in BTNR as a percentage of those in Singapore. It clearly demonstrates that BTNR is a biodiversity hotspot that must be conserved.

This Comprehensive Biodiversity Survey of BTNR has resulted in the collection of much scientific data, spanning from ecosystem to species and genetic levels, and covering terrestrial and aquatic biodiversity. The synthesis of the results of the survey reaffirms that biodiversity research in Singapore as illustrated in this survey has matured and has attained another quantum level. We now not only record occurrences of species but also place emphasis on quantitative counts (Cai et al., 2019; Cheong, 2019; B.C. Ho et al., 2019; Karam \& Chong, 2019; Khew \& Tan, 2019; Koh \& Court, 2019; Li et al., 2019; Lim, 2019; Teo \& Thomas, 2019), document ecological interactions (Ascher et al., 2019; Cai, 2019; Cai et al., 2019; Cheong, 2019; J.K.I. Ho et al., 2019; Khew \& Tan, 2019; Khoo et al., 2019; Koh \& Court, 2019; Li et al., 2019; Lim, 2019; Seow-Choen et al., 2019), carry out DNA- barcoding (Grootaert \& Foo, 2019; J.K.I. Ho et al., 2019), and link biotic and abiotic factors (Cai, 2019; Chatterjea, 2019; Nyugen \& Cai, 2019). Many more analyses will be possible from these invaluable datasets accumulated during this exercise.

BTNR offers an excellent study site for researching issues such as the sustainability of small tropical rainforest fragments, the elucidation of a conservation quagmire like how small is too small to sustain a tropical forest plot, and the importance of connectivity with other forested areas for natural resource and gene exchange, etc. For more productive analyses, it is, hence, crucial that the rich data on the biodiversity and physical environments of BTNR continue to be expanded upon by the coordination of research and long-term monitoring efforts.

Since BTNR used to be connected with CCNR and the last comprehensive survey of CCNR was carried out in the 1990s, it is timely that a survey, similar in 
Table 3. Species diversity in Bukit Timah Nature Reserve in comparison with that known from the whole of Singapore.

\begin{tabular}{|c|c|c|c|c|}
\hline & Topic & $\begin{array}{l}\text { No. of species in } \\
\text { BTNR }\end{array}$ & $\begin{array}{l}\text { No. of native } \\
\text { species in } \\
\text { Singapore }\end{array}$ & $\begin{array}{l}\% \text { of species in BTNR } \\
\text { compared to the } \\
\text { whole of Singapore }\end{array}$ \\
\hline 1 & Flora & 1208 & 2215 & 55 \\
\hline 2 & Macrofungi & 230 & Data deficient & Data deficient \\
\hline 3 & Amphibians & 21 & 25 & 84 \\
\hline 4 & Reptiles & 60 & 102 & 59 \\
\hline 5 & Mammals & 34 & 61 & 56 \\
\hline 6 & Birds & 146 & 403 & 36 \\
\hline 7 & Spiders & 317 & More than 800 & $\sim 40$ \\
\hline 8 & Bees & 55 & 130 & 42 \\
\hline 9 & Butterflies & 63 & 334 & 19 \\
\hline 10 & $\begin{array}{l}\text { Dragonflies and } \\
\text { damselflies }\end{array}$ & 55 & 131 & 42 \\
\hline 11 & Moths & 399 & Data deficient & Data deficient \\
\hline 12 & Orthoptera & 83 & 245 & 34 \\
\hline 13 & Saproxylic beetles & 53 & Data deficient & Data deficient \\
\hline 14 & Neurigona spp. & 3 & 5 & 60 \\
\hline 15 & Stick insects & 11 & 44 & 25 \\
\hline 16 & Freshwater fishes & 16 & 85 & 19 \\
\hline 17 & $\begin{array}{l}\text { Freshwater decapod } \\
\text { crustaceans }\end{array}$ & 8 & 21 & 38 \\
\hline
\end{tabular}

scope, be initiated for CCNR. The recent research on the hydrology and biodiversity of Nee Soon freshwater swamp forest (Davison et al., 2018) in addition to the many other papers published on CCNR can already set the impetus of a multi-disciplinary and holistic survey of CCNR.

The successful long-term conservation of BTNR depends on delicately balancing multiple factors, including the diverse requirements of different taxonomic groups, management for varied purposes like conservation, scientific research, and 
diverse types of recreation. The complexity of the issue at hand is far beyond simple methods of analyses. We are fortunate that modern technology has developed tools in modelling that will be able to assist us make sense of this wealth of data that have been accumulated by a dedicated group of the best available expertise in Singapore.

ACKNOWLEDGEMENTS. We thank all the authors of papers in this volume resulting from the comprehensive survey of Bukit Timah Nature Reserve, and in many cases their assistants, teams of collaborators and family members for their help and understanding. We thank the Central Nature Reserve Branch in particular, Sharon Chan, Cheryl Chia and Chew Ping Ting, for their strong support. We thank the editorial team of Gardens' Bulletin Singapore for their tremendous help in publishing this series of papers. We thank HSBC for financial support and for participation by their staff volunteers in the vertebrate survey. Funding from NParks is acknowledged. Members of the Nature Reserve Scientific Advisory Committee provided advice and guidance. To everyone who has played a part in one way or another in making the Comprehensive Biodiversity Survey of BTNR a reality, we say Terima kasih, Xie xie, Nantri and Thank you.

\section{References}

Ascher, J.S., Soh, Z.W.W., Ho, B.M., Lee, R.Y.Y., Leong, A.Q.E., Chui, S.X., Lai, J.J.L., Lee, J.X.Q., Foo, M. \& Soh, E.J.Y. (2019). Bees of the Bukit Timah Nature Reserve and vicinity Gard. Bull. Singapore 71 (Suppl. 1): 185-208.

Balke, M., Hendrich, L. \& Yang, C.M. (1997). Water beetles (Insecta: Coleoptera) in the Nature Reserves of Singapore. Gardens' Bulletin Singapore, 49(2): 321-331.

Burslem, D.F.R.P., Grubb, P.J. and Turner, I.M. (1995). Responses to nutrient addition among shade-tolerant tree seedlings of lowland tropical rain forest in Singapore. J. Ecol. 83: 113-122.

Cai, Y. (2019). Hydrogeomorphic characteristics of streams in Bukit Timah Nature Reserve, Singapore Gard. Bull. Singapore 71 (Suppl. 1): 441-490.

Cai, Y., Nga, Y.P.Q. \& Ngiam, R.W.J. (2019). Diversity and distribution of dragonflies in Bukit Timah Nature Reserve, Singapore. Gard. Bull. Singapore 71 (Suppl. 1): 293-316.

Chan, L. \& Corlett, R.T. (eds.) (1997). Biodiversity in the Nature Reserves of Singapore. Gardens' Bulletin Singapore, 49(2): 145-425.

Chan, L. \& Davison, G.W.H. (2019). Introduction to the Comprehensive Biodiversity Survey of Bukit Timah Nature Reserve, Singapore, 2014-2018. Gard. Bull. Singapore 71 (Suppl. 1): 3-17.

Chatterjea, K. (2019). Bukit Timah, a forest in transition. Gard. Bull. Singapore 71 (Suppl. 1): 419-440.

Chen, J., Turner, I.M., Saunders, R.M.K. \& Thomas, D. C. (2018). Artabotrys scortechnii (Annonaceae): an augmented species description and a new record for Singapore. Gard. Bull. Singapore 70(1): 3-8.

Cheong, L.F. (2019). Estimating saproxylic beetle (Coleoptera: Cerambycidae and Buprestidae) diversity in Bukit Timah Nature Reserve, Singapore, with a methodological and biological review. Gard. Bull. Singapore 71 (Suppl. 1): 339-368.

Chew, P.T., Saifuddin Suran \& Ali Ibrahim. (1997). Checklist of vascular plants in the Nature Reserves of Singapore. Gard. Bull. Singapore 49(2): 161-223. 
Chin, S.C., Corlett, R.T., Wee, Y.C. \& Geh, S.M. (eds.) (1995). Rain Forest in the City: Bukit Timah Nature Reserve, Singapore. Gard. Bull. Singapore Suppl. 3: 1-167.

Corlett, R.T. (1991). Plant succession on degraded land in Singapore. J. Trop. For. Sci. 4: $151-161$.

Corlett, R.T. (1997). The vegetation in the Nature Reserves of Singapore. Gard. Bull. Singapore 49(2): 147-159.

Chua, S.C., Ramage, B.S., Ngo, K.M., Potts, M.D. \& Lum, S.K.Y. (2013). Slow recovery of a secondary tropical forest in Southeast Asia. For. Ecol. Manage. 308: 153-160.

Chong, K.Y., Tan, H.T.W. \& Corlett, R.T. (2009). A Checklist of the Total Vascular Plant Flora of Singapore: Native, Naturalised and Cultivated Species. Singapore: Raffles Museum of Biodiversity Research.

Chung, Y.F., Wong, T.W. \& Chan, S. (2018). Eco-Link@BKE: A safe corridor for our biodiversity. CITYGREEN 12: 92-95

Courtney, L. A. \& Clements, W. H. (1998). Effects of acidic pH on benthic macroinvertebrate communities in stream microcosms. Hydrobiologia, 379: 135-145.

Davison, G.W.H., Cai, Y., Li, T.J. \& Lim, W.H. (2018). Integrated research, conservation and management of Nee Soon freshwater swamp forest, Singapore: hydrology and biodiversity. Gard. Bull. Singapore 70 (Suppl. 1): 1-7.

Davison, G.W.H. \& Chew, P.T. (2019). Historical review of Bukit Timah Nature Reserve, Singapore. Gard. Bull. Singapore 71 (Suppl. 1): 19-40.

Davison, G.W.H., Ng, P.K.L. \& Ho, H.C. (eds) (2008). The Singapore Red Data Book: Threatened Plants and Animals of Singapore, 2nd ed. Singapore: Nature Society (Singapore).

Department of Statistics Singapore (2018) Singapore in Figures 2018. Available from www. singstat.gov.sg. Accessed 28 Feb 2019.

Ercelawn, E.C., LaFrankie, J.V., Lum, S.K.Y. \& Lee, S.K. (1998). Short-term recruitment of trees in a forest fragment in Singapore. Tropics 8: $105-115$.

Feldman, R. S. \& Connor, E. F. (1992). The relationship between $\mathrm{pH}$ and community structure of invertebrates in streams of the Shenadoah National Park, Virginia, USA. Freshwater Biol. 27: 261-276.

Goldsmith, G.R., Comita, L.S. \& Chua, S.C. (2011). Evidence for arrested succession within a tropical forest fragment in Singapore. Jour. Trop. Eco. 27: 323-326.

Grootaert, P. \& Foo, M. (2019). The springtail catchers of the genus Neurigona (Insecta, Diptera, Dolichopodidae) in the old-growth forest of Bukit Timah Nature Reserve, Singapore. Gard. Bull. Singapore 71 (Suppl. 1): 369-379.

Gupta, A. (1992). Physiography of the Bukit Timah Nature Reserve and the Central Water Catchment area: a preliminary report. Unpublished report, pp. 1-43. Reports on the Nature Reserves Survey (Phase I). National Parks Board, Singapore.

Ho, B.C. (2002). A comparative study of moss biodiversity in selected lowland rain forests in Johor (Peninsular Malaysia) and Singapore. ScholarBank@NUS Repository. Available at http://scholarbank.nus.edu.sg/handle/10635/149443 (Accessed 31 Jan 2019).

Ho, B.C. (2013). The liverwort genus Marchantia L. (Marchantiophyta: Marchantiopsida) in Singapore, with a new species record. Nat. Singapore 6: 187-190.

Ho, B.C., Lua, H.K., Leong, P.K.F., Lindsay, S., Seah, W.W., Bazilah Ibrahim, Loo, A.B.H., Koh, S.L., Ali Ibrahim \& Athen, P. (2018). New records and rediscoveries of vascular plants in Bukit Timah Nature Reserve, Singapore. Gard. Bull. Singapore 70 (1): 33-55. 
Ho, B.C., Lua, H.K., Bazilah Ibrahim, Yeo, R.S.W., Athen, P., Leong, P.K.F., Ali Ibrahim, Koh, S.L., Hassan Ibrahim, Lindsay, S., Chin, L.L., Seah, W.W. \& Middleton, D.J. (2019) The plant diversity in Bukit Timah Nature Reserve, Singapore. Gard. Bull. Singapore 71 (Suppl. 1): 41-134.

Ho, J.K.I., Foo, M., Yeo, D.C.J. \& Meier, R. (2019). The other 99\%: exploring the arthropod species diversity of Bukit Timah Nature Reserve, Singapore. Gard. Bull. Singapore 71 (Suppl. 1): 391-417.

Huber, B.A., Koh, J.K.H., Ghazali, A.R.M, Braima, K.A., Nuñeza, O.M., Leh Moi Ung, C. \& Petcharad, B. (2016). New litter-dwelling species of the genus Pholcus from Southeast Asia (Araneae, Pholcidae). Euro. Jour. Taxo.200: 1-45.

Kang, N. (1992). The birds and mammals of the Central Catchment area: a preliminary report. Unpublished report, Reports on the Nature Reserves Survey (Phase I). National Parks Board, Singapore.

Karam, R. \& Chong, J.H. (2019). Moths of Bukit Timah Nature Reserve, Singapore. GGard. Bull. Singapore 71 (Suppl. 1): 317-330.

Kenzo, T., Kamiya, K., Ngo, K.M., Faizu, N., Lum, S.K.Y., Igarashi, S., Norichika, Y. \& Ichie, T. (2019). Overlapping flowering periods among Shorea species and high growth performance of hybrid seedlings promote hybridization and introgression in a tropical rainforest of Singapore. For. Eco. Manage. 435: 38-44.

Khew, S.K. and Neo, S.S.H. (1997). Butterfly biodiversity in Singapore with particular reference to the Central Catchment Nature Reserve. Gard. Bull. Singapore 49: 273-296.

Khew, S.K. \& Tan, H. (2019). Butterflies of the Bukit Timah Nature Reserve, Singapore, and its vicinity. Gard. Bull. Singapore 71 (Suppl. 1): 273-292.

Khoo, M.D.Y., Tiong, N.J.L., Li, T., Lim, W., Ng, D.J.J., Nyanasengeran, M., Yeo, D.C.J. \& Cai, Y. (2019) The freshwater decapod crustaceans of Bukit Timah Nature Reserve, Singapore. Gard. Bull. Singapore 71 (Suppl. 1): 575-581.

Khoo, M.S., Chua, S.C. \& Lum, S.K.Y. (2018). An annotated list of new records for Singapore: results from large-scale tree surveys at the Bukit Timah Nature Reserve. Gardens' Bulletin Singapore, 70: 57-65.

Koh, J.K.H. \& Court, D.J. (2019). Spider diversity in the Bukit Timah Nature Reserve, Singapore. Gard. Bull. Singapore 71 (Suppl. 1): 209-243.

LaFrankie, J., Davies, S.J., Wang, L.K., Lee, S.K. \& Lum, S.K.Y. (2005). Forest Trees of Bukit Timah. Population ecology in a tropical forest fragment. Singapore: Simply Green.

Lee, S.M.L. (2019) Macro-fungal diversity of Bukit Timah Nature Reserve, Singapore. Gard. Bull. Singapore 71 (Suppl. 1): 135-144.

Lee, S.S., Horak, E., Alias, S.A., Thi, B.K., Nazura, Z., Jones, E.B.G. \& Nawawi, A. (2008). Checklist of Literature on Malaysian Macrofungi. Available at https://www.mybis.gov. my/pd/70. Accessed: 21 May 2016.

Li, T.J., Loh, Y. X., Lim, W.H., Nyanasengeran, M., Low, B.W., Tan, H.H., Yeo, D. C. J. \& Cai, Y. (2019). The fish fauna of Bukit Timah Nature Reserve, Singapore. Gard. Bull. Singapore 71 (Suppl. 1): 559-575.

Lim, K.K.P. (1995). Fishes. Gard. Bull. Singapore (Suppl. 3):159-163.

Lim, K.S. (1997). Bird biodiversity in the Nature Reserves of Singapore. Gard. Bull. Singapore 49: $225-244$.

Lim, K.S. (2019). Birds of Bukit Timah Nature Reserve, Singapore. Gard. Bull. Singapore 71 (Suppl. 1): 185-208. 
Lim, R.C.J., Lindsay, S., Middleton, D.J., Ho, B.C., Leong, P.K.F., Niissalo, M.A., van Welzen, P.C., Esser, H.-J., Ganesan, S.K., Lua, H.K., Johnson, D.M., Murray, M.A., LeongŠkorničkováJ., Thomas, D.C. \& Ali Ibrahim (2018). New records and rediscoveries of plants in Singapore. Gard. Bull. Singapore 70(1): 67-90.

Murphy, D.H. (1993). On preparatory work towards a survey of the invertebrate animal life of the Central Catchment Nature Reserves in Singapore. Interim Report, part 1 and 2. Unpublished reports on the Nature Reserves Survey (Phase I). National Parks Board, Singapore.

Murphy, D.H. (1997). Odonata biodiversity in the nature reserves of Singapore. Gard. Bull. Singapore 49: 333-352.

National Parks Board of Singapore (2015). Nature Conservation Masterplan. Unpublished. National Parks Board, Singapore.

Ng, P.K.L. (1997). The conservation status of freshwater prawns and crabs in Singapore with emphasis on the Nature Reserves. Gard. Bull. Singapore 49: 267-272.

Ng, P.K.L. \& Lim, K.K.P. (1997). The diversity and conservation status of fishes in the Nature Reserves of Singapore. Gard. Bull. Singapore 49: 245-265.

Ngo, K.M., Davies, S., Nik Faizu Nik Hassan \& Lum, S. (2016). Resilience of a forest fragment exposed to long-term isolation in Singapore. Plant Ecol. Divers. 9: 397-407.

Nguyen, C.T.T. \& Cai. Y. (2019). Physicochemical characteristics of streams in Bukit Timah Nature Reserve, Singapore. Gard. Bull. Singapore 71 (Suppl. 1): 491-556.

Piipo, S., He, X.L., Juslan, A., Tan, B.C., Murphy, D.H. \& Pocs, T. (2004). Hepatic and hornwort flora of Singapore. Ann. Bot. Fennici, 39: 101-127.

Seow-Choen, F. (1997). Stick and leaf insect (Phasmida: Insecta) biodiversity in the Nature Reserves of Singapore. Gard. Bull. Singapore 49(2): 297-312.

Seow-Choen, F. (2017). A Taxonomic Guide to Stick-Insects of Singapore. Kota Kinabalu: Natural History Publications (Borneo).

Seow-Choen, F., Seow-En, I., Chua, E.K. \& Choo, M.E. (2019). A survey of stick-Insects in Bukit Timah Nature Reserve, Singapore: 2015-2016. Gard. Bull. Singapore 71 (Suppl. 1): 381-389.

Shono, K., Davies, S.J. \& Chua, Y.K. (2006). Regeneration of native plant species in restored forests on degraded lands in Singapore. For. Ecol.Manage. 237: 574-582.

Shono, K., Davies, S.J. \& Chua, Y.K. (2007). Performance of 45 native tree species on degraded lands in Singapore. J. Trop. For. Sci 19: 25-34.

Singapore Bird Group (2018). Singapore Bird Group. Nature Society (Singapore). https://singaporebirdgroup.wordpress.com/tag/. Accessed 31 January 2019.

Stewart, A.D. (1931). Notes on a visit to the Malay Peninsula. Indian Medical Gazette, August 1931: 457-465.

Tan, M.K. (2019). Orthoptera species checklist of Bukit Timah Nature Reserve in the Zoological Reference Collection, Singapore. Gard. Bull. Singapore 71 (Suppl. 1): 331-338.

Teo, R.C.H. \& Rajathurai, S. (1997). Mammals, reptiles and amphibians in the Nature Reserves of Singapore - diversity, abundance and distribution. Gard. Bull. Singapore 49(2): 353-425.

Teo, R.C.H. \& Thomas, N.J. (2019). Updated inventory of the amphibians, reptiles and mammals of the Bukit Timah Nature Reserve, Singapore. Gard. Bull. Singapore 71 (Suppl. 1): 145-183.

Tham F.Y. \& Watling, R. (2017) Annotated checklist of macrofungi recorded from Singapore: Bukit Timah. Singapore. 
Tong, Y.F., Koh, J.K.H., Tong, X.J. \& Li, S.Q. (2016). Five new species of the genus Ischnothyreus Simon, 1893 from Singapore. ZooKeys 618: 39-66.

Turner, I.M., Tan, H.T.W. \& Chua, K.S. (1992). A botanical survey of the Nature Reserves. Unpublished report, pp. 1-27. Reports on the Nature Reserves Survey (Phase I). National Parks Board, Singapore.

Turner, I.M., Tan, H.T.W., Chua, K.S. \& Metcalfe, D.J. (1994). Recent botanical collections from the Nature Reserves of Singapore. Gardens’ Bulletin Singapore, 46(2): 1-36.

Turner, I.M., Wong, Y.K., Chew, P.T. \& bin Ibrahim, A. (1997). Tree species richness in primary and old secondary tropical forest in Singapore. Biodivers. Conserv. 6(4), pp.537-543.

Wee, Y.C. \& Haji Mohamed (1995). Bryophytes. Gard. Bull. Singapore Supplement No. 3: 71-76.

Yang, C.M., Lim, K.K.P., Lua, H.K. and Yeo, K.L. (1992). A report on the preliminary Nature Reserves survey of insects, amphibians and reptiles of the Central Catchment area. Unpublished report, pp. 1-12. Reports on the Nature Reserves Survey (Phase I). National Parks Board, Singapore.

Yang, C.M., Lua, H.K. \& Yeo, K.L. (1997). Semi-aquatic bug (Heteroptera: Gerromorpha) fauna in the Nature Reserves of Singapore. Gard. Bull. Singapore 49(2): 313 - 319.

Yap, F., Yong, D.L., Low, B.W., Cros, E., Foley, C., Lim, K.K. \& Rheindt, F.E. (2014). First wintering record of the Sakhalin Leaf Warbler Phylloscopus borealoides in South-East Asia, with notes on vocalisations. Birding ASIA, 21: 76-81 